\title{
The Pacific Ocean and the Californias. POWER RELATIONS AND TRADE ON THE PERIPHERY OF THE NEW SPAIN (1565-1775)
}

\author{
Miguel Ángel Sorroche Cuerva \\ University of Granada
}

Resumen: La definición de los extremos del itinerario que estableció el galeón de Manila a partir de 1565, con especial atención al frente norteamericano en el que las Californias se convirtieron desde inicios del siglo XVII en un punto básico de la política internacional española en el Pacífico, corrobora el proceso de control territorial que se había iniciado ciento cincuenta años antes, evidenciando la importancia que adquirió el Mar del Sur como espacio de relación. Si bien no podrán ser tratados todos los aspectos que consideramos implicados para comprender el proceso analizado, en el caso de las Californias, su papel fue paulatinamente más importante desde que se establecieron de un modo definitivo los primeros asentamientos misionales.

Palabras clave: Pacífico, Californias, poder, comercial, Nueva España.

AbSTRACT: The definition of the itinerary poles that Manila's galleon established from 1565, with special attention to the North-American front in which the Californias were a basic point for Spanish international politics, confirm the territorial controlling process that was started 150 years earlier, showing the importance that the southern sea acquired as a connecting space. Although not all of the aspects that we consider to be involved in the analysed process can be targeted to understand it, in the case of the Californias, its role became gradually more important from the establishment of the first missionary settlements.

Keywords: Pacific, Californias, power, commercial, New Spain. 


\section{INTRODUCTION}

$\mathrm{T}$ he discovery of the Pacific in 1513 marked a fundamental date in the historical development of the events that were occurring at that time in America. A vast scenario ensued within which the integral perception of the planet would be completed, through which the possibilities of relations between different regions in the world were broadened and diversified. This event somehow invites us to consider the facts that were yet to occur from that date on, constructing the pillars for the knowledge of Spanish history in these territorial boundaries, as well as each of the territories that flanked its coast.

Amongst these territories, the Californias stood out as a frontier area, with two different aspects in this condition, although integrated within its role as a historical region. Its prominence as an exchange and relations area with the Pacific background evidences its importance in consolidating this area of the viceroyalty of New Spain, defining Spanish international politics as a result of a long process which began in the 16th century.

The chronological spectrum chosen and defined in this article covers the time between the establishment of the trip around Urdaneta, that will periodically take the Manila galleon to these coasts, and the foundation of San Francisco, the last settlement with a strong strategic value that showed the Spanish interests in this region and where the religious, military and civil components were the face of a system that was constructed and used since the end of the 17th century. Its international dimension is perhaps another reason to look back at this immense ocean, and rethink its role in the northwest front of New Spain's frontier between the 16th and the 18th centuries, and as a main context of the power and commercial exchange relations between the different nations present there. The historical unfolding will show the need to join the pieces of the disjointed jigsaw in order to understand not only the relations within an area connected by two poles, but also to raise multiple questions concerning the intermediate area.

\section{The PaCific AND ITS COASTS}

This is an area for exchange and relationships that has been questioned because of its dimensions and the underestimation of human capabilities to get along in it. Focus has swung between theoretical speculation concerning the routes of human population groups in the American continent, ${ }^{1}$ and the

\footnotetext{
1. Its dimensions have always been behind the aim to explain theories about the movements of human groups or along itself, or of the relationships between these putting in contact north and south American contexts from its oriental coast and being essential to understand the development of some civilization focus such as the case of the Andean region. Cf. PABLO MARTínez DEL Río: Orígenes del hombre americano. [1987], Conaculta, México,1997; Diego Andrés Rocha: El origen de los indios. (José Alcina Franch ed.), Historia 16, Madrid, 1998; y PAul Rivet: Los orígenes del hombre americano. [1943], FCE, México, 1987.
} 
evidence that relationships with European nations that fought for the control of this area throughout the Modern Age resolved its potentiality.

The territories that constituted the Californias and that currently conform the Mexican peninsula of Low California and the North American California, were, between the 16th and the 18th centuries, the scenario of conquest, occupation and evangelization politics determined by two fronts, one terrestrial and one maritime. In the first case, the terrestrial front, the connection with the continental area will provide a long distance with the decision-making areas that will be decisive, and also geography and climate and the characteristics of the human groups and formed its population. In the second case, the maritime front, this was open to an uncertain horizon that will turn into a tremendously intense and dynamic one and, as in the first case, become conditioned by travelling distances.

The letter that father Piccolo sent to Juan Maria Salvatierra in 1699 describing an expedition to the Pacific Coast of the low California peninsula is illuminating. It reveals how 134 years after Juan de Urbieta completed the trip from the Philippines archipelago, there was not a safe area to which the galleons could reach and avoid the English and Dutch assaults, showing some aspects of a reality that would be defined over the passage of time. ${ }^{2}$

The 18th century was noticeable for the expulsion of the Jesuits from the Hispanic territories under the reign of Carlos III, the arrival of the Franciscans, its posterior relocation in North American California from 1769, and the incorporation of the yearned for Camino de las Californias of the Dominicans from 1573. In both cases the interest of the territorial control was moved to the northern area that had been coveted since the 16th century. The Russian presence, more evident towards the south coast in trying to secure its fur factories, reflects the incorporation of new protagonists in the process. Somehow the importance of the commercial exchange of the Galleon was affected by the profitability of the transported goods, and thus the political interests to control it were emphasized.

In the first quarter of the 19th century (and in the middle of it), the independence processes and the start of the frontier adjustments meant that the last missionary foundations in this coastal area were the prelude to future changes. The secularization of these missionary foundations ended a process in which the religious orders had been participating since the end of the year five hundred and been responsible for the religious and the political aspects of an action to consolidate a space that was unequally appreciated by the crown. This was the end point of a long period during which the lack of power emerged that, disabled to control a growing territory, used the most diverse formulas to be present in the areas that were remote from the decision centre

2. The news is essential for understanding the origin of the presence of a variety of objects that comprised the ecclesiastical goods, constituted by Asian Philippine or Japanese pieces and will corroborate later the Jesuit Miguel del Barco. 


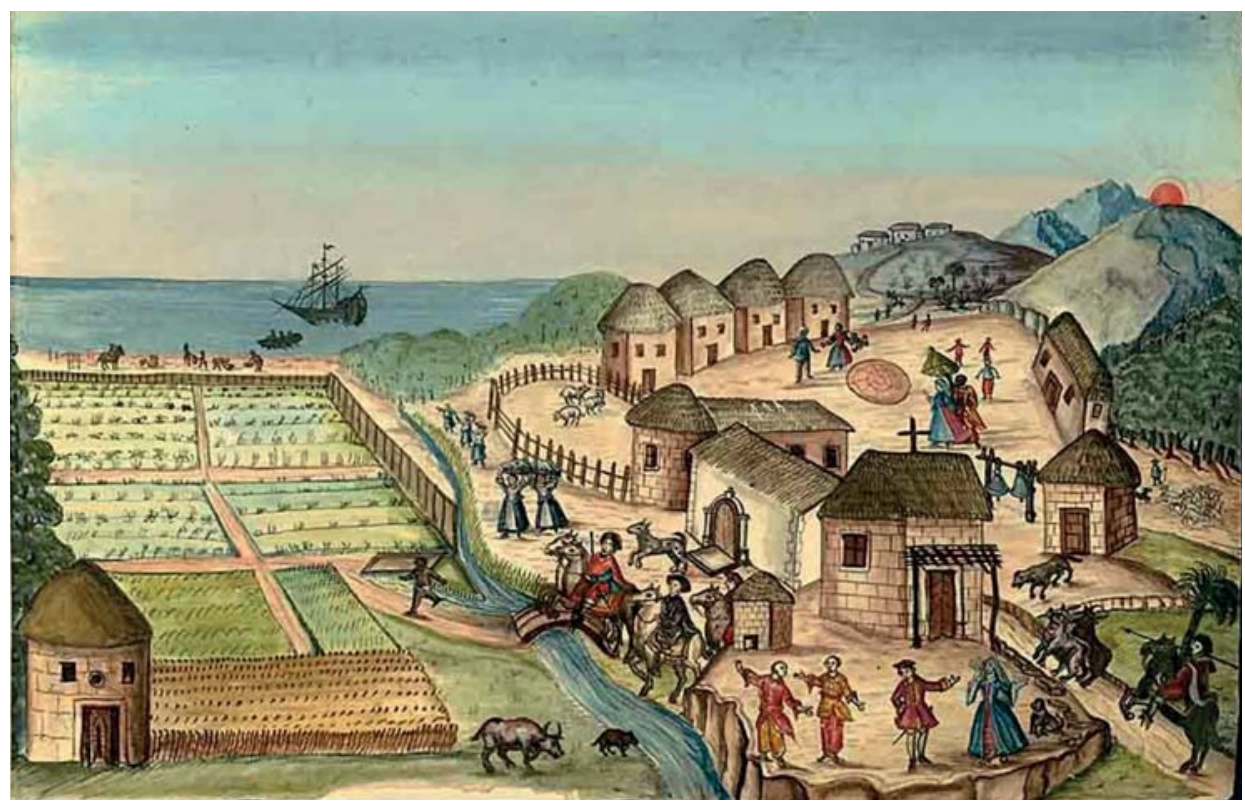

Illustration 1. Mission of San José del Cabo. Ignaz Tirsch. 1767

and where the image of this presence ranged from small objects to the military control of the territory.

Although this could be, broadly speaking, a description of the Californian situation, the broad context of the Pacific shows its complex dimension. We have stipulated how the Pacific Ocean has extended as a context where theoretical reflections and hypotheses have tried to explain historical processes such as the repopulation of the American continent. However, the knowledge of its reality was evidenced from the beginning when the population groups at the coasts showed their awareness of the existence of the others distributed along its geography. Only the events that occurred from 1513 and between 1519 and 1522 marked an ontological process that made the idea of its reality conformed along with the expeditions that went through from the north to the south of its oriental front and the maritime movements that were established from east to west. ${ }^{3}$

From the beginning, the need for defence was evident. The distance and the characteristics of the Pacific Coast determined the defensive program that will seize it. In the case of the northern coast it will be completed with the presence of presidios that made a fortress such as Acapulco an outstanding milestone. There are only some topographic or toponymic testimonials and minimal archaeological remains from those, showing the loss of architectural

3. The trip around the world of Magallanes and Juan Sebastián and the event derived from it caused it to be incorporated into the European horizon progressively. 
forcefulness but not of effectiveness in designing a program to control the coast and the entries to the inland. In any case it systematically represents the intention of the crown in this part of the empire, far removed from the programs developed in the context of the South Pacific around Valdivia, nor even near to the program designed in the Philippines, and indeed very distant from the forcefulness of the Caribbean-Atlantic program. ${ }^{4}$

On the other hand, the western coast of the Pacific presented a dynamic context in which the journeys between the different territorial areas of the southeast had been occurring during the past centuries and that was open to the circuits of the Indian Ocean. This was an area with natural relationships within contexts such as the African or Indian, it had been controlled by cultures such as Muslim since the 7th century in different periods if time, and the commercial domain in the area was a reflection of this. This area therefore represented an historical reality suggestive of the links between the human groups from the first century A.C., in a progression that will be renowned in the 15th century. ${ }^{5}$ In this reality we cannot forget the Portuguese presence from the end of that century that made it a context known in Europe, and this will become consolidated over the 16th century with the foundation of some essential settlements such as Macao. ${ }^{6}$

That unbalanced situation (unlike the American coast where there were no main centres for exchange) made it possible for cities such as Manila to become a commercial reference in the region. Here Chinese, Indian and Japanese products converged that went from one place to another along the different routes that used the Philippine capital as a compulsory exchange and meeting point that will intensify from the 16th century. This strategic importance, as well as the density of the movements and the geographical characteristics of the narrow straits between the islands, made the new military construction policies completely different to those that had been in place up until that moment. The British presence in Manila between 1762 and 1764 and the subsequent Dutch presence marked both moments as turning points that was reflected in a reconstruction of the military complex and an increase of it in some sectors where the weight of the architectural work was carried by the religious orders such as the Jesuits or the Augustinians, reproducing an interesting multiplicity of roles that had been observed in other contexts.

4. In each of the three spheres described, the programs developed stand out as an example of the continuity of the construction system on the other side of the Pacific, see MARÍA LOURDES DíAz-TRECHUELO SPínola: Arquitectura española en Filipinas (1565-1800), EHH, Sevilla, 1959.

5. With respect to this subject cf. Luce Boulnois: La ruta de la seda. Dioses, guerreros y mercaderes, Península, Barcelona, 2004.

6. The presence and competition of two of the Iberian powers in the Orient has been adressed by different authors, as well as the European expansion from the 15th century around territories far from Europe. Evidently within this dynamic the American adventure has been included, that with another two incidents will allow us to confirm a real image of the spaces around that area. Cf. JOHN H. PARRY: Europa $y$ la expansión del mundo. 1415-1715. [1949], FCE, México, 2003; J.R.S. PHILlips. La expansión medieval de Europa. [1988], FCE, México, 1994; and Claude CAHEN: Oriente y occidente en tiempos de las cruzadas. [1983], FCE, México, 2001. 


\section{CAlifornia in the American And EUropean imaginary}

Returning to the Californian territories, the perception about them was related to their extreme position in New Spain. The limits of the known earth have always been an open space for imagination due to a lack of awareness about them. The Californias, remote areas located at the north of Anahuac, were always associated with fantasist interpretations regarding their origin and nature because of their remote position in the image of both the preHispanic populations and the subsequent European ones, and this determined its representation through the 17 th and 18 th centuries. ${ }^{7}$

In pre-Hispanic cosmology, the image of the Californias was included within the conception about the place where the Sun would set, Tonatiuh. The belief that the Sun will go across the sky after travelling through Mictlan and win the fight against the night forces became a representation of the sphere into which two of the most respected social prototypes within the pre-Hispanic world will go after death. On the one hand, the soldiers fallen in combat will become the court that will escort the Sun from its rise until the zenith, whereas from this point until the sunset, women who have fallen while giving birth will escort it and will prepare it for its nocturnal fight. These cihuateotl, magestically represented in the sculptural complex in Zapotal, are the feminine contribution that caused this coastal region to soon become linked with a group of women that will live on an island, and constituted one of the first verifications of the cross between pre-Hispanic and Europeans that occurred in the American context. ${ }^{8}$

On the other hand, for the Europeans, the same localization in the border of the known earth captured many of the images that had been generated since the antiquity, where the wild and incredible settled without problems, in spite of the descriptions given to it from infernal to heavenly, mainly in the 18th century. ${ }^{9}$

In this context we should include the Californian area, within the broader context of the new Spanish North, in which Fray Marcos de Niza described cities such as Quivira or Cibola, and that were represented and located in some maps that incorporated them into the American imaginary thanks to expeditions such as the one by Alvar Nuñez Cabeza de Vaca.

7. See one of the most complete repertoires of the representations in Low California, cf. MigueL LEónPortilla: Cartografía y crónicas de la antigua California, UNAM, México, 2001.

8. Miguel Ángel SorRoche Cuerva: «Tradición indígena y leyenda medieval: la representación gráfica de lugares fantásticos», in InMaculada Rodíguez Moya y Víctor Mínguez: Arte en los confines del Imperio, Universitat Jaume I, Castellón de la Plana, 2011, 151-174.

9. «In this regard, the Greeks imagined mythic populations with wild qualities and barbarian features: gryphon, cynocephalus, wild cálibes, savage amazons, lotófago, Gorgonas, etc., but also wonderful places such as the island of Gereión, the islands of the Blessed and the Atlantis of Platón. Countries of Gods, countries of the dead, in conclusion, wonderful countries». SAlvador bernabéu Albert: "California, o el poder de las imágenes en el discurso y las misiones jesuitas», Contrastes. Revista de Historia, 12 (20012003), 159-185, specifically 164. 


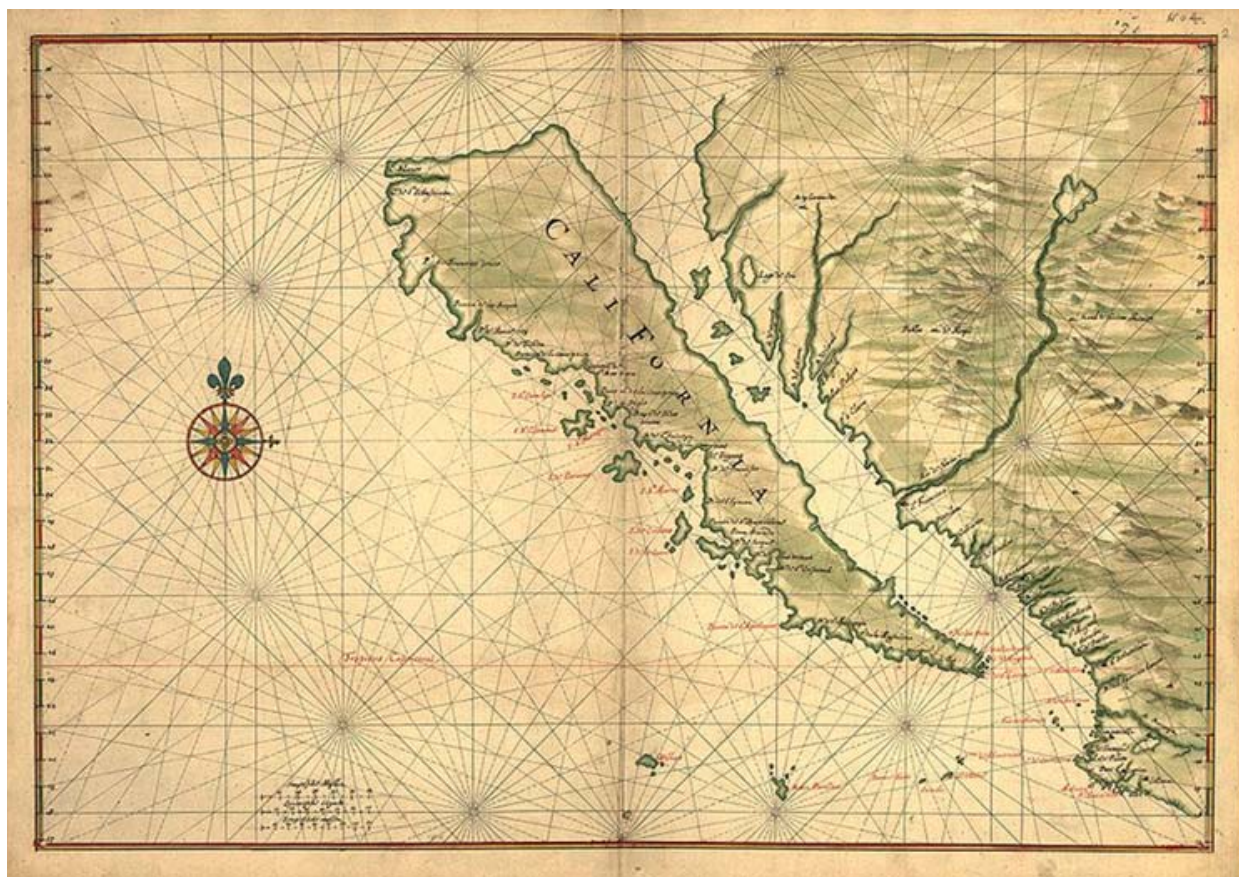

Illustration 2. Island of California. Johannes Vingboons. 1650

This imaginary representation will become more exact as a result of the descriptions from the expeditions that will occur across its coast from the beginning of the 17th century. This representation of its coast impeded a better knowledge of the inland - this will have to wait for the incursion commanded by religious groups such the Jesuits and the Franciscans during the last quarter of the 17th and mainly during the 18th century. These incursions were supported in many cases by the native groups. ${ }^{10}$ This fact can be appreciated in the representation of the peninsula, in that it shows it neither as a peninsula nor an island. In any case, the North was a linked space with the unknown that covered the image of this new Spanish northern sector, inheriting the preHispanic image of this point of the geography.

\section{Power RELATIONSHips in the CALifornias}

The discovery of the South Sea in 1513 by Nuñez de Balboa did, without a doubt, corroborate the suspicions surrounding these lands, as well as those

10. With respect to the confirmation of these territories there is a variety of works: We refer to the two that represent the characteristics of them. Íñgo AbBAD y LASIERRA: Descripción de las costas de California, CSIC-Instituto Gonzalo Fernández de Oviedo, Madrid, 1981; and MARía Luisa RodríGUEz SAla: Exploraciones en Baja y Alta California, 1769-1775: escenarios y personajes, unAM, México, 2002. 
concerning the true dimension of the endeavour that began at this time. Only a few centuries later (in the 18th century) the scientific expeditions will not only allow the technical control of the territory, when the members of the expeditions were not only religious and military but also military engineers, but also to have the perspective from the precise knowledge of its profile and conditions, as mentioned in the previous section. ${ }^{11}$ These circumstances were not supported by the crown, whose hesitation was reflected in unequal treatment from a defensive point of view compared to other sectors of the Pacific Coast, unlike the system developed in other contexts.

The apathy in defending this vast flank was caused by the length and the characteristics of its coasts. Historical evolution suggests the opposite. The Spanish endeavour in this region was slowly undermined by the presence of British and Dutch ships that would seriously impact the strategy developed since the 16th century. The course of the Manila galleon in North American coasts and its derivation towards the southern port of El Callao soon saw how some of its galleons such as the Santa Ana were captured, proving their vulnerability. ${ }^{12}$ This situation ultimately worried the viceroys, as demonstrated in some of their memoirs in which the dimension of the factors playing a role in the coastal sector of New Spain was explained..$^{13}$

The enormous construction work carried out in the Caribbean was justified because this was the central point from which the commerce was organized through the Carrera de Indias that reached the Iberian Peninsula. It served as an agent of change for a series of tensions around its forks, including the Pacific, and the added presence of other nations that wanted to control this commerce, along with the presence of pirates. Facing this area the investments in the Pacific, conditioned by the extension of its coast, were reduced to specific spaces. Some of these spaces stood out because of their complexity, such as the fort complex in Valdivia, Chile, but lacked the integrity of its previous one.

11. Cf. Guadalupe pinzón Ríos: «Una descripción de las costas del Pacífico novohispano del siglo XVIII», EHN, 39 (julio-diciembre 2008), 157-182.

12. The awareness of the dimensions of the enterprise made the Spanish crown accept the presence of ships from other powers such as France, that with the permits could sail around these areas complementing the works that couldn't be controlled and that reflects a constant in Spanish politics in America that can be explained because of the impossibility of confronting such a vast enterprise on its own.

13. In relation to this, it is significant that the signature of the viceroy Jose Miguel de Azanza (17981800), even though outside of the period analysed here clearly shows the integrated components in the whole process that we study, particularly the military and the commercial processes. From the naval station of San Blas, I should speak about subjects concerning the military area. Nothing I will say to your Excellence about the movement of those short naval forces to the port of Acapulco, a subject on which enough has been written in the last two governments. The truth is that, whether in one or the other place, enough ships are needed to carry the memories to the Californias, High and Low, and let's hope so that were also capable of protecting our commerce and navigation in the whole of the South Sea belonging to New Spain. Nowadays that small marine is reduced to the corvettes Princesa and Concepción, brigantines Activo and Valdés, sloop Horcasitas and schooners Sutil and Mexicana, with two gunboats. The corvette Aránzazu that went to Manila has been rendered useless, and it is uncertain, as just as your Excellence will see according to the correspondence from the general captain of those islands, if it will be replaced or not...». ERNESTO DE LA TORRE Villar: Instrucciones y memorias de los Virreyes Novohispanos, T. II, Porrúa, México, 1991, 1366-1367. 
In the Californian case, an enormous importance was given to both the geographical determinants of the design of the structural program and to the historical conditions of the region in which the support for the religious work also played an important role. Not long after, the native populations started insurrection actions and the pressure increased from the European powers that were competing to control the riches that were generated from the strip mining of the deposit and the commercial routes, both land and maritime, in the region. ${ }^{14}$

On the opposite side of the Pacific, the distance and the need to confront a context with an intense traffic that historically directed the products that arrived to the Manila port from China, India, or Japan, resulted in the concurrent foundation of the settlements; some of the most important forts in the region were built, such the forts in San Fernando in Cebu, Santiago in Manila, San Fernando in Taiwan as well as minor structures that controlled the strategic crossing between the islands. In the same context we should include the religious buildings that in the case of the Philippines acquired characteristic physiognomies, where the structures of the towers were integrated into components of the defensive system. They enclose a complex structural system of the territory, in which they stand out not only because of its strategic location but also because of its dimensions, as in the case of the Paoay and Laoay.

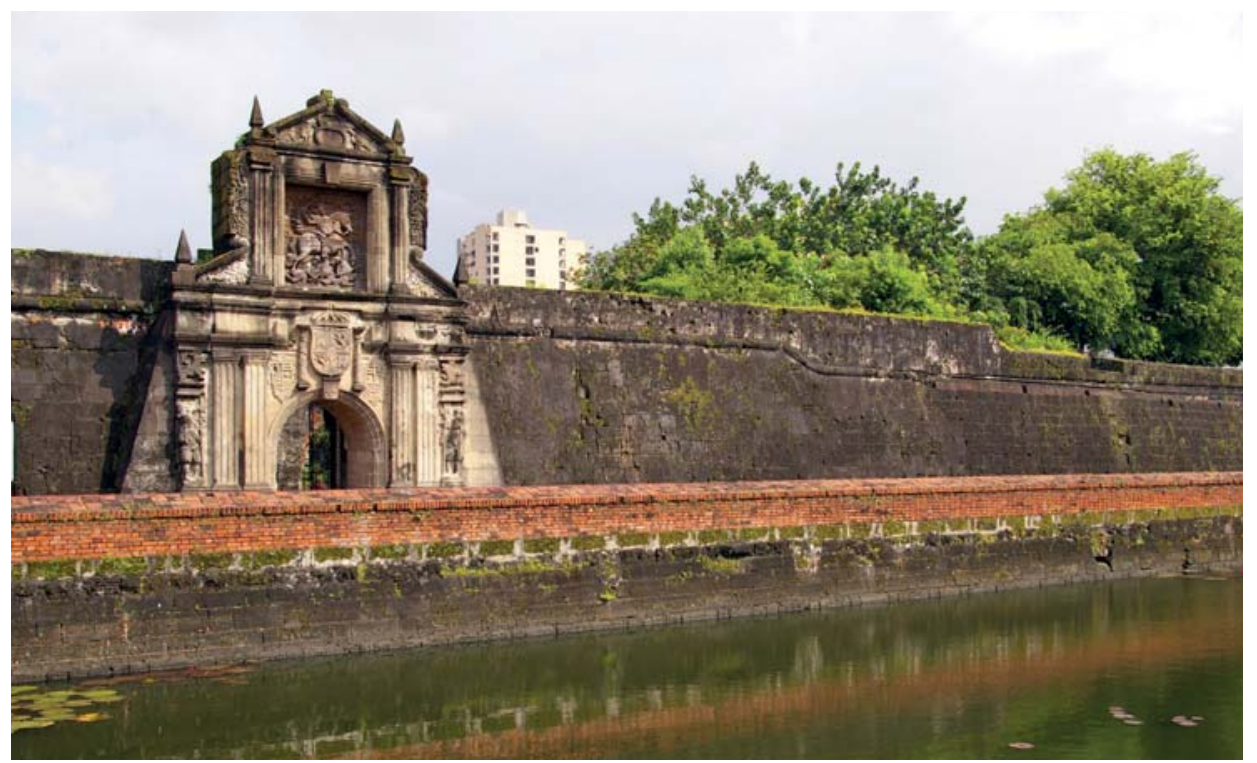

Illustration 3. Fort of Santiago. Manila. 16th century

14. The complexity of the network that was established and that was partly dependent on the existing pre-Hispanic has been treated in various occasions. However, we refer to Ramón María Serrera: Tráfico terrestre y red fluvial en las Indias españolas, Ministerio del Interior-Lunwerg editores, Madrid-Barcelona, 1992. 
In the light of this, the situation of the Californian coast was very characteristic as an intermediate point within an itinerary in which it worked as an inflexion area and the centre of a context already controlled in its ends, but that was necessary to strengthen in the intermediate areas because of the vulnerability of the galleons that arrived after their journey through the Pacific.

\section{The Californias and the North West frontier of New Spain}

The reason for its importance has been a subject of debate over recent years. As we pointed out, in the case of the Californias the real and the mythical are two sides of the coin, breathing life into the idea of its exceptional nature that distinguishes it from other contexts. ${ }^{15}$

The territories of the north of New Spain conformed a broad space in which a wide range of different situations occurred due to its social, geographical and frontier characteristics. Distant from the decision centres, the dynamics characterized by the lack of control that caused a development that was independent from the managing processes and made the presence of the power visible that managed the new situation. From Florida to the Pacific coast, the need for its control brought the proliferation of the duties of the institutions involved that developed into specific regimes depending on the spheres and that were particularly unique to the Californias ${ }^{16}$ It was an adaptation process to the new realities that the new protagonists of the colonization process faced and that defined what would later become the very popular mission-presidio structure in the New Vizcaya area at the end of the 16th century. ${ }^{17}$

In our specific case, from the end of the 17 th century until the first half of the 19th century, the missions that Jesuits, Franciscan and Dominicans founded from the far south of the peninsula of Low California to the San Francisco Bay Area not only evangelized the native populations but also acquired an integrated role in the international politics of the Spanish crown. Their ambition was to secure their presence with an effective control over the territory represented in the military component of the action. This was initially reflected in the participation of the military, whose effective presence with the construction of presidios such as the Loreto, was a clear example of

15. Authors such as Salvador Bernabeu Albert say that: «As well as its geostrategic position in the Northwest of North America, a territory wanted first by the Russians and later by Anglo-Americans, the California was an important peninsula because of its frontier use, similar to the hespérides in the Classic Age. These mythical islands were situated in the ends of occident in the habitat earth, the oikouméne of the Greeks, and there were a garden of gold apples in it». SAlvador BernAbÉU Albert: «California, o el poder de las imágenes...», op. cit., 159-185, specifically 164.

16. With respect to the characteristics that the government of Low California acquired from 1697, referring to IgNACIO DEL Río: El régimen jesuitico de la Antigua California, UNAM, México, 2003.

17. PAtricia Osante: «El septentrión novohispano: una secular colonización hispana», in SAlvador Bernabéu Albert (Coord.): Poblar la inmensidad: sociedades, conflictividad y representación en los márgenes del Imperio Hispánico (siglos XV-XIX), Ediciones Rubeo, Madrid, 2010, 43-106. 


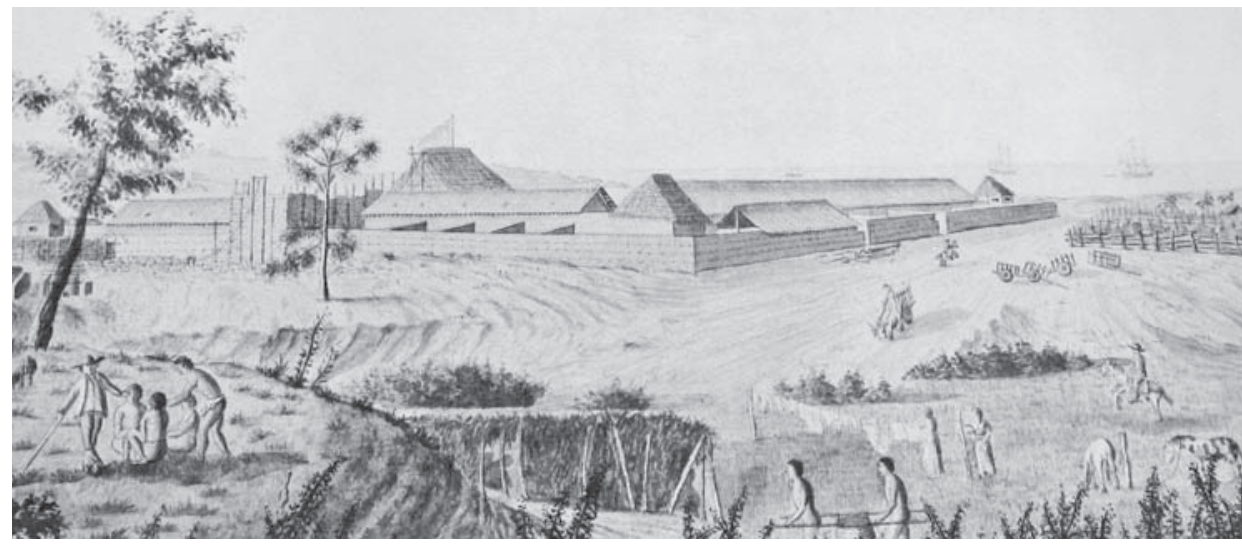

Illustration 4. Presidio's Monterey. California. Drawing by José Cordero. 1791

the role of the forces that implied the presence of soldiers. Other components that can describe this process are structural details in Jesuit buildings, the defensive structures integrated in the Dominicans in the Pacific Coast of the construction of four presidios in San Diego, Santa Barbara, Monterey and San Francisco in High California from 1769.18

Returning to the missions as an important unit, their exposure to the external pressure forced them to have a noted role in the territorial organization in the region, where they operated within a process marked by different phases such as exploring, conquering, and colonization. ${ }^{19}$

These missions, part of programs that derived from the ones used in America by religious orders since the 16th century, stand out for the eloquent imagery of the process in which they were involved. Plastic and symbolism were united both in the decorative programs of the interiors, in which the objects coming from the orient played an important role due to their exoticism and the attraction they created, and the configuration of the cultural scenery. In this scenery, the instruments were designed that were needed for the development of the exploitation works of the territory where the control of water imposed a discipline that was used as a way of indoctrination into the programs developed by the missionary, and also the use of craft workshops. This complexity surpassed the main role of the most known element, the church, and it shows a complex control mechanism that has not been appreciated by the

18. The relationship between the missions and presidios and their links between them is another aspect described in the work of Martha Ortega Soto. Alta California: una frontera olvidada del noroeste de México. UAM-Plaza \& Valdés, México, 2001.

19. The consolidation of the processes from which the conformation in different previous phases obliges us not to miss the previous periods developed within New Spain to understand the mechanisms used in the same way as we should value the experience in the peninsula to understand the enterprise in America from 1492 and the exportation to the Philippines since 1565.Cf. Ostwald Sales Colín: El movimiento portuario de Acapulco. El protagonismo de Nueva España en la relación con Filipinas, 1587-1648, Plaza y Valdés, México, 2000, 43-52. 
historiography that centred its attention on the most prominent components. The territorial dimension is therefore omitted as it is inserted in a bigger and immaterial one.

The final result was the necessary acceptance of the special circumstances that were involved in that territory, which forced the design of an occupation model in which the protagonists, the State, the Church, and the civil population, delegated roles and generated a process of inequality.

The union of politics and religion was not new, but the conditions in which the most tenacious order landed in that territory was defining a regime with which it had full autonomy to accomplish some roles that lead to some conflicts with the military elements present, and mainly with a civil component that sometimes emerged from the military apparatus and that required equal treatment for access to the exploitation of the riches in the territory.

During the process of configuration two phases can be distinguished. The first phase was developed mainly in Low California between 1697 and 1767, in which the occupation of the territory barely had military presence apart from the construction of the Loreto prison as an evident element, and the second phase between 1768 and 1776, during which the Jesuits and the San Francisco mission were expelled, and in which the military component was developed unequally both in the Low California and the High California territories. During this second period we can identify a first phase with the Dominican missions that were founded between San Fernando de Velicata and San Diego from 1769 , where the presence of defensive elements were noticed such as the fort of the Santo Domingo mission and that complemented a strategic disposition of the religious foundations that will be reconverted when the commerce with otter skin developed by the Russians started. And the most evident phase from 1769 , when the control of the coast is more direct, evidenced by the change in Spanish politics facing the presence of the British and Russians. This affected an articulation of the territory and the mission processes with the presence of four main presidios, San Diego, Santa Barbara, Monterey and San Francisco. ${ }^{20}$

\section{The CONTRol of THE terRitory. A Defined Method}

On October $7^{\text {th }} 1699$, Father Francisco Maria Piccolo was on a journey from the Loreto mission to the Pacific Coast of the Low California peninsula in order to, among other things, locate a favorable port in which the Manila Galleon could layover. The extract of the letter that was addressed to Juan Maria Salvatierra dated at the end of the month October and that can be found complete in the

20. The complexity of the group of elements that are involved in this frontier configuration reflects the different crossed interests that existed in the process. Cf. LUIS ARNAL: «El presidio. Instrumento de población en el septentrión novohispano», in SAlvador Bernabéu Albert (Coord.), Poblar la inmensidad: sociedades, conflictividad y representación en los márgenes del Imperio Hispánico (siglos XV-XIX), Ediciones Rubeo: Madrid, 2010, 117-124. 
National Library of Mexico, is essential to our understanding of the method developed by the Jesuits in Low California, sometimes describing the situations that allow understanding of the general dynamic, the end of it being its most significant aspect. ${ }^{21}$

This epistolary information no only offers a variety of descriptions that allows us to have an idea of the reality of Low California but also conveys a description of the constant contact with the native populations that are in many cases new groups that approach the religious and that were fairly unknown. In addition, this is an example of the two pillars that underlie the process, the political and the religious, that in any case opens up questions concerning the historical dynamic that was occurring and shows that it does not circumscribe to the time of narration but is projected to past and future periods, allowing a tremendously suggestive contextualization. ${ }^{22}$

The missionary journey was an excuse to offer contributions to various aspects that we can apply to the whole of the Californian territory, given its singularity as the periphery and frontier of New Spain, where the geographical and population characteristics should be framed within the general context of the so-called Aridoamerica, with the determinism that this implies in the development processes of human groups that swarm in this areas.

The importance of the role that the Jesuit gave to the public ceremony and sound, even the basic sound of bells, became a generalized habit and practised by the natives in the early years such as 1699 , which talks about the assimilation of the evangelizing and indoctrination processes: «... the reception given to us by the sons (that we have in this village) with various bows and bell ringing...» as a sample of it. ${ }^{23}$ What is also in itself interesting is the reference to the components to a mayfly architecture that was present in different levels of complexity in New Spain from the 16th century, perhaps becoming more important in the following centuries. It is interesting because it was a public demonstration of representative elements and symbols of the community life and of the educating role of the religious as a community activity that helped to offer a higher significance to the acts that it decorated. ${ }^{24}$

21. IgnaCio del Río (ed.): Crónicas jesuíticas de la Antigua California. UNAM, México, 2000, 19-29.

22. Descriptions of ceremonies, dates about climatology and details about the territory, information about church construction practices during its essential phases and descriptions of the different populations with which language, social behavior, etc., were crossed, are just an innumerable series of proposals for approaches that are open for us, encouraging us to develop each one of them.

23. IgnaCio del Río (ed.): Crónicas jesuíticas..., op. cit., 19.

24. An example of the mayfly architecture that was carried out in Mexico in the 16th century is reflected in the work of Francisco Cervantes de Salazar: México en 1554 y Túmulo Imperial, Editorial Porrúa, México, 1972. 


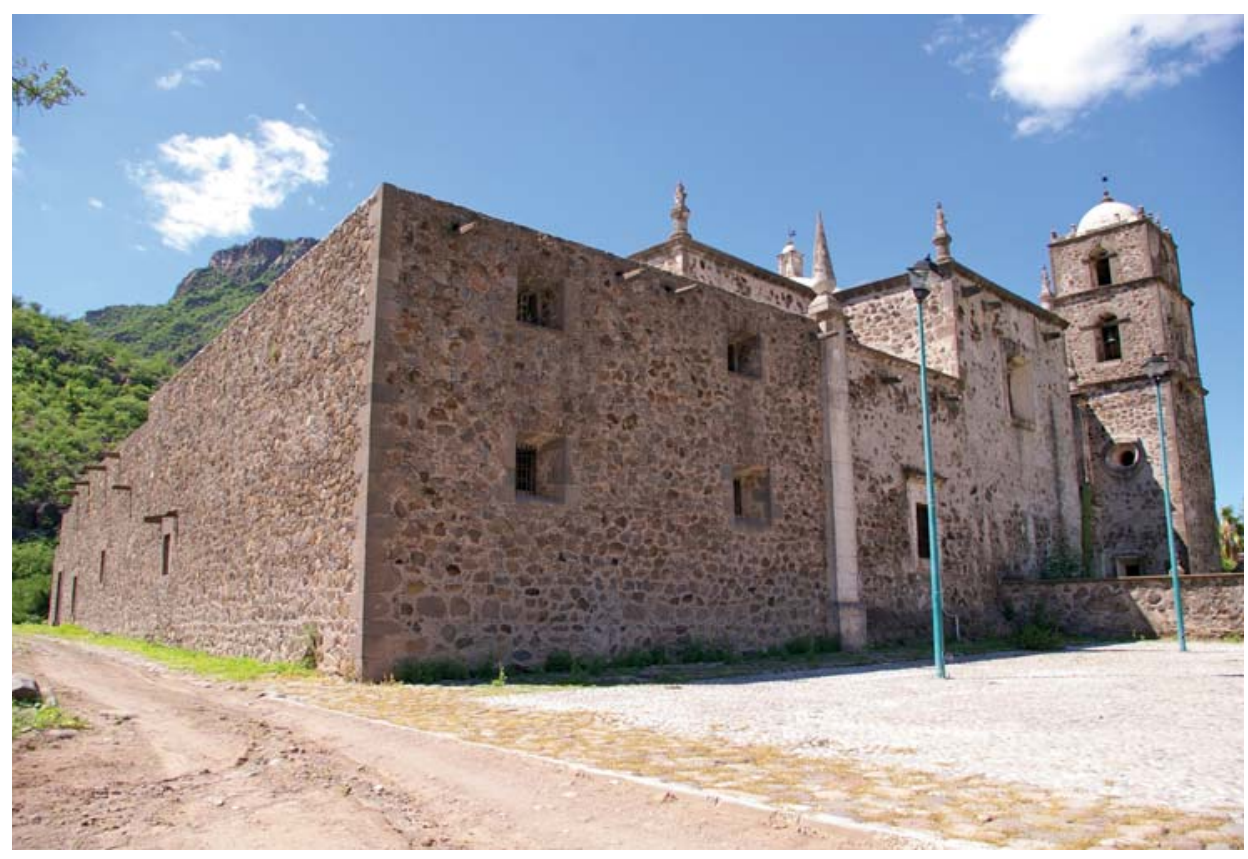

Illustration 5. Mission Church of San Francisco Javier Biaundó. 1756

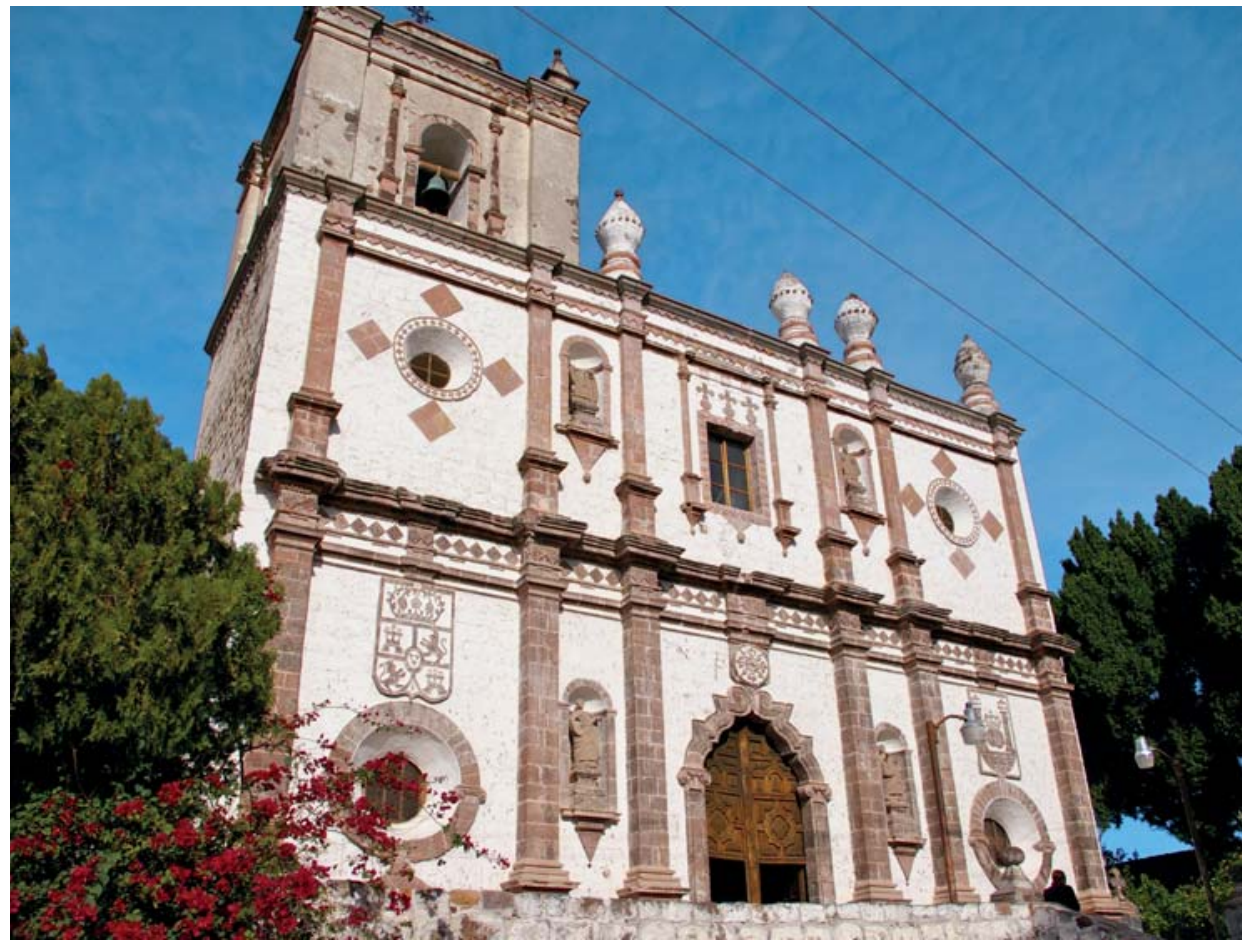

Illustration 6. Mission Church of San Ignacio Kadakaamang. Low California. México. 1786 
This letter is also an inestimable source to understand the mechanism the religious groups used to enter into this inhospitable territory. The role of the native in the journeys completed by the Jesuits as well as in the places selected to found the mission was essential due to the speed with which the foundations were created, and the strong symbolic role that they had in being historic points for meetings or water supply integrated within a symbolic geography that gives a special role to the landscape as the scenery of daily nature. ${ }^{25}$ For this, the process of gathering information prior to the start of the journey from San Francisco Javier to the countercoast is critical to understand the occupation process. ${ }^{26}$

As mentioned earlier, the Evangelical work implied from the beginning the availability of the necessary elements for it, where the construction of the church was fundamental. Although the materials available are stone and earth as well as vegetables for the construction of the roofs, the references to the construction of the first church in the San Francisco mission suggest the use of adobe as a material that allows us to understand the system used in other missions, given that this one was the second constructed in Low California. The fact that the material used was adobe, and also the time taken was two days, gives the impression that it was a well-known construction technique used not only by the religious but also by the soldiers in charge of the protection of these missions. In the military detachment number 14, the soldiers made 2500 adobes in two days to construct a chapel, seven yards long and four-anda-half yards wide, and two days was also the time they needed to construct a residence for father Francisco Maria Piccolo and another two days to cover the church with fodder. ${ }^{27}$

In addition to the religious, another sphere that shows the power relationships established is that of the military. Addressing the awareness of the presence of the Spanish power in a context such as the Pacific cannot be separated from the general politics used in New Spain, from the military component of it or from the territorial consequences that ensued in other contexts and which became apparent as the frontier moved towards the north. In this sense, the military organization of the region could barely adapt to the programmed system. These circumstances made the figure of the governor an essential role in these territories along with the general captain. However, we

25. Rosa Elba Rodríguez Tomp: Los límites de la identidad. Los grupos indígenas de Baja California ante el cambio cultural, Gobierno del Estado de Baja California Sur-Instituto Subcaliforniano de Cultura, La Paz, 2006.

26. «while he was taking tongue and notice of the path and distance that was from this area to the sea of the countercoast ...». IGNACio DEL Río (ed.): Crónicas jesuíticas..., op. cit., 20

27. «...wanted the captain (Antonio García de) Mendoza with the soldiers to make some adobes for the new chapel of San Francisco Javier. Divided in two teams of seven soldiers (each one), they made in two days two thousand and five hundred adobes. And the captain, who started the work, made with his partner five hundred adobes the first morning, and the other team, in the evening, made six hundred adobes (...). In conclusion, the colleagues made, in two days, the chapel of seven yards long and four yards wide. In another two days they wanted to build for me, underserving, a settlement and a room, and in another two days they covered the chapel that, even made of fodder, was beautiful». Ibidem, 20. 
assert that these characteristics were variable in each region of this vast area to the extent that the link in the Californian case between religion and politics forced a new solution to be found for the imposition of the reality that those who wanted to control it had to face. ${ }^{28}$

In the light of this, the two fronts in the new sea that were open to the Spanish domains required an integral policy based on a constructive program in which the Spanish sovereign would instigate. The change from the Medieval to the Modern Age brought a change in the attack systems that required an improvement in the military structures used so far. ${ }^{29}$ The European approach found that America was the setting to combine their static proposals with the dynamics of a commercial fleet that had to protect, in a combination of components that made the American reality become complex were, as already mentioned, not only piracy but also the pressure from powers such as England and Holland which made its presence necessary.

In any case the complexity of the American reality made the defensive typologies adapt to the different cases, from the proposals to defend the coast towns for layover and fleet concentration to the one that will control the internal frontiers both in disputes with the native groups and other European powers. The techniques applied came from the experience with the Italian and Dutch academies, of particular note being the formation of the Barcelona Royal Group of Engineers and the Academy for Prospero Verboom. ${ }^{30}$

As we mentioned earlier, the Pacific front was recognized from the perspective of its difficult access and its distance, although it was one of the characteristics that affected the whole of the fleets, including the Spanish one. This situation created some doubts concerning the proceeding strategy, either a dynamic defensive system using the floats or the static system using the forts, without considering of using both, and in the case of California, none of them being used in the end.

This did not avoid the inequality in the elements that will be constructed, because although there was a program designed for the Chilean, Peruvian and Ecuadorian coasts, the Mexican coast barely had elements from the Acapulco fort and (from the 18th century) from the San Diego, Santa Barbara, Monterey and San Francisco presidios, that, in 1775 would be the last intervention in this northern region.

28. VIRGINIA GUEDUA: «La organización militar», in WoOdROw BoraH: El gobierno provincial en la Nueva España. 1570-1787, UNAM, México, 2002.

29. The dominant position of Spain in the Mediterranean context and its internal progression reflected in the development of the Granada war, brought about in the 16th century the conformation of a civil and military architectural Academy that was suggested to be supported by Juan de Herrera. His links with Italy meant that very soon the transalpine engineers served the King of Spain as in the case of Tiburcio Spanoqui, who had a confirmed experience in constructing the forts in the Mediterranean against the Turkish. Cf. Ramón Gutiérrez: Arquitectura y urbanismo en Iberoamérica, Cátedra, Madrid, 1983, 299-320.

30. Josep Soler Vidal: California: la aventura catalana del noroeste, FCE, México, 2012; J.O. Moncada Maya: «Ingenieros militares en California. Siglo xviı»» en J.O. Moncada. (Coord.): Fronteras en movimiento. Expansión en territorios septentrionales de la Nueva España, Instituto de GeografíaUNAM, México, 1999. 


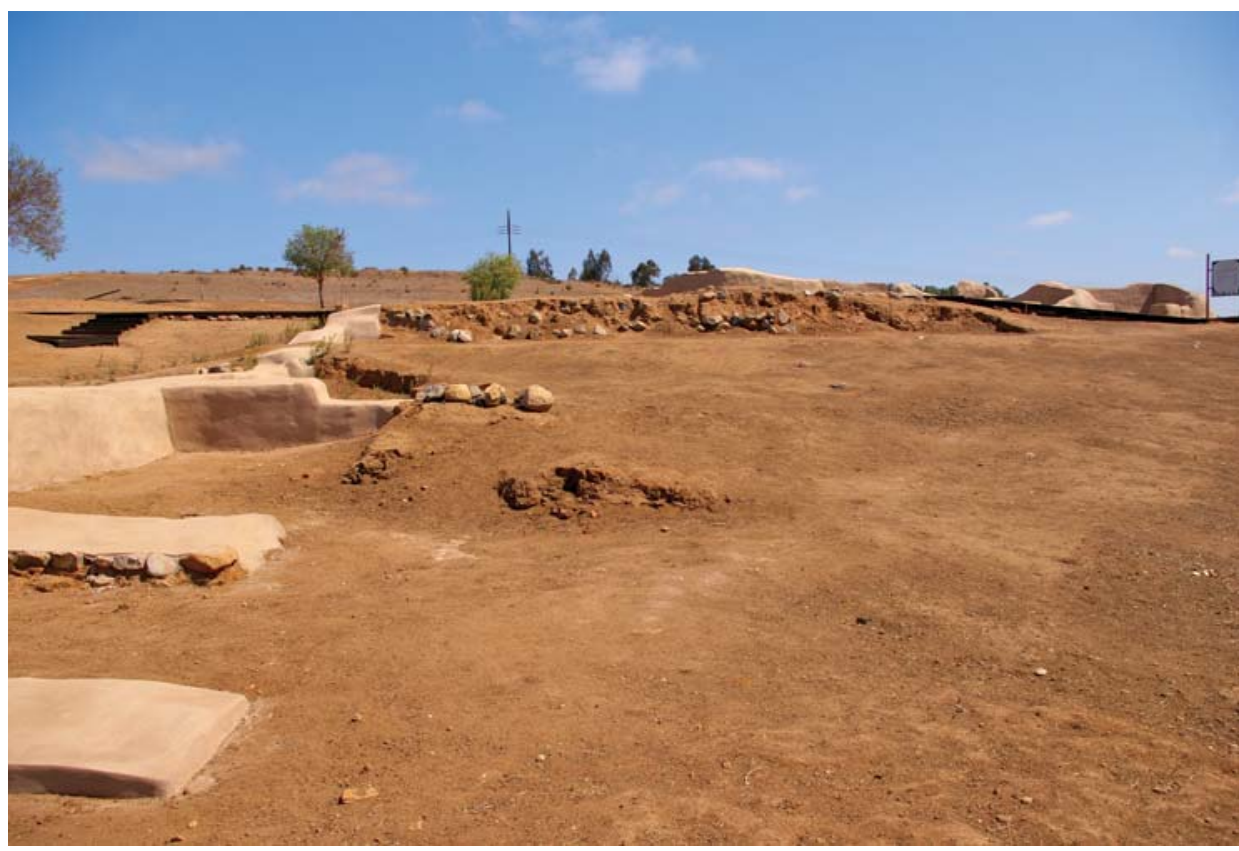

Illustration 7. Mission of San Vicente Ferrer. Baja California. 1780

This contrasted with the effort to militarize the new open front in Asia. Unlike California, the attention paid to the new spaces controlled in the Philippine archipielago, (although we cannot forget others such as Guam or the Marianas islands), depicts an intense construction process that can only be explained in terms of the pressure of being a context perfectly defined by the competition in the control for the different commercial routes. The construction of forts such as the Cebu, Manila, Palawan or Taiwan and other minor ones like the isle of Escarpada, would explain the concerns about potential invasions in this other area.

Contrary to the Californian case, the existence of threats from the beginning, where the native groups and the Asian and European powers were combined, resulted in the occupying mechanisms then being incorporated more than in the American context, the presence of the military structure being essential to protect the population, and also where the religious orders participated during the 18th century. The construction of fences is part of a methodology that was practised since the beginning in America, to the extent that we cannot forget that the Philippine context was the second occasion when the Spanish crown had to confront the invasion of an insular area.

Undoubtedly, the perception of this region during the second half of the 16th century was more consistent. The politics developed by Felipe II in these territories were marked by constant religious fights, where the Jesuits certainly had an impact on increasing the pressure on them, showing the contact but not 


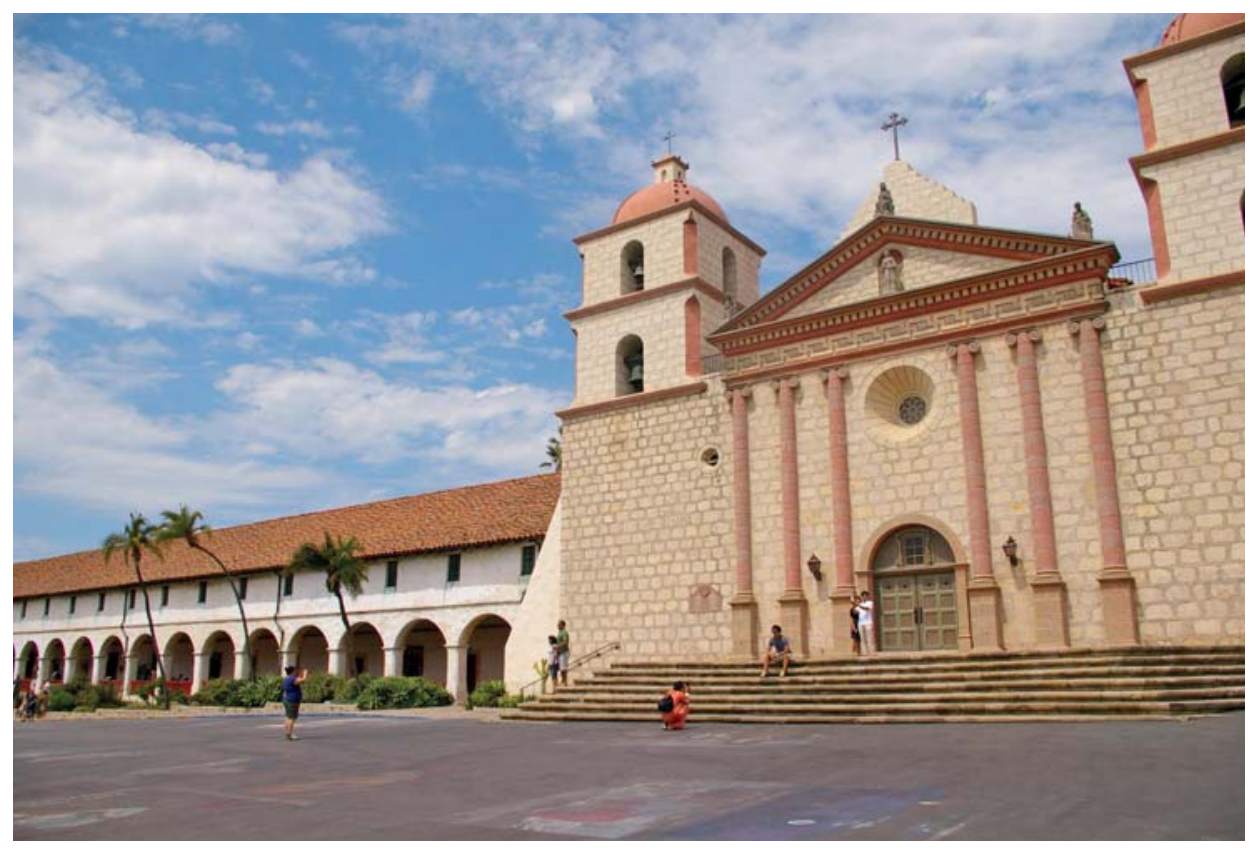

Illustration 8. Mission of Santa Bárbara. California. 1786-1925

the exact knowledge of the Asian realities since their presence in these areas since the decade of the 40s of the 16th century with San Francisco Javier. ${ }^{31}$

In all of this, the need to secure a pathway out for the ships from Manila that had, since 1565, established regular contact with the Pacific countercoast, resulted in this unequal development expressed in the complex buildings that are currently a clear testimonial of this historical epoque. 